\title{
Implementation of Integrated Science Model With Audiovisual Teaching Materials To Improve Students' Learning Outcomes and Science Process Skills
}

\author{
Emilia Candrawati ${ }^{1}$, Sumpono $^{2}$, Agus Sundaryono ${ }^{3}$, Mellyta Uliyandari ${ }^{4}$ \\ 1,2,3,4 Universitas Bengkulu, Bengkulu, Indonesia
}

\begin{tabular}{|c|c|}
\hline 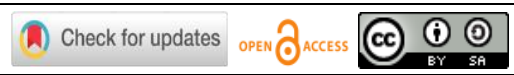 & DOI : https://doi.org/10.46245/ijorer.v1i2.34 \\
\hline Article Info & ABSTRACT \\
\hline $\begin{array}{l}\text { Article history: } \\
\text { Submitted: June 12, } 2020 \\
\text { Final Revised: July 11, } 2020 \\
\text { Accepted: July 12, 2020 } \\
\text { Published Online: July 31, } 2020 \\
\text { Keywords: } \\
\text { Audiovisual } \\
\text { Integrated science } \\
\text { Science Process Skill } \\
\text { Teaching materials } \\
\square\end{array}$ & $\begin{array}{l}\text { This study aims to determine the effectiveness of the integrated } \\
\text { science learning type connected to achieving basic competencies and } \\
\text { improving science process skills. This study uses a 4-D development } \\
\text { model that is defined, design, develop, and disseminate with one- } \\
\text { group posttest design implemented in } 5^{\text {th }} \text {-semester students of } \\
\text { Chemistry Education, University of Bengkulu. The research } \\
\text { instrument is a posttest question to measure learning outcomes and } \\
\text { observation sheets to measure science process skills. The teaching } \\
\text { materials used are sourced from part of the process and the results of } \\
\text { the activity test of palm oil endophytic bacteria ethyl acetate extract } \\
\text { against Fusarium oxysporum f.sp. by TLC-bioautography is packaged } \\
\text { in the form of learning videos. The results showed that the Integrated } \\
\text { Science type of Connected model was used effectively to improve } \\
\text { student learning outcomes and science process skills. The integrated } \\
\text { science type connected learning model can make students have direct } \\
\text { experience so that they can add strength to receive, save, and apply } \\
\text { the concepts they have learned. The mastery of students' science } \\
\text { process skills namely the ability to observe, interpret, and } \\
\text { communicate is in the high category, except the ability to apply } \\
\text { concepts that are only in the sufficient category. More in-depth } \\
\text { research on science process skills for all indicators is strongly } \\
\text { recommended to obtain more comprehensive results. }\end{array}$ \\
\hline
\end{tabular}

\section{INTRODUCTION}

The quality of education in Indonesia today is quite worrying. This can be seen in Indonesia's achievements in 2018 which only ranked 72 out of 77 participating countries (Organisation for Economic Co-operation and Development, 2019). The decline in Indonesia's ranking is due to the low competence of teachers in facilitating learning. Pratiwi (2019) states that Indonesia needs to change policies to improve the quality of education, one of which is through curriculum improvement.

Conventional learning models often ignore process skills, which are abilities developed during learning. The process skills include the ability to observe, classify, measure, communicate, interpret, and conclude (Prabowo, 2015). As a result, the ability of students to master and understand the material, especially in the field of science (science), is relatively low.

Conventional learning models is not only applied by teachers, but also by lecturers. This has implications for the low mastery of prospective teacher students in mastering science process skills. For this reason, efforts are needed to improve the ability of the 
scientific process of prospective teacher students so that they have overall competence in mastering science learning materials.

Integrated Science learning model is a learning model to foster students' process skills in teaching and learning activities. Trianto (2014) states that through integrated learning, students can gain direct experience so you can add strength to receive, save, and apply the concepts he has learned. Thus students are trained to be able to discover for yourself the various concepts learned as a whole (holistic), meaningful, authentic, and active. Tawil \& Liliasari (2014) revealed that science process skills are an approach that allows students to discover facts, develop concepts, through activities and or experiences such as scientists. Karamustafaoglu (2011), said that many students' abilities related to science process skills could not develop properly because the students had difficulty connecting things learned with problems that exist in everyday life. By applying the integrated science learning model, it is expected to be able to give meaning to students by mastering process skills that can be implemented in the real world.

Fogarty formulated ten models that are used in integrated learning which is consists of fragmented, connected, nested, sequenced, shared, webbed, threaded, integrated, immersed, and networked. The learning model used in this research is focused on the connected model. According to Fogarty (Ridyah, 2016), a connected model is: "the model focuses on making explicit connections with each subject area, connecting one topic to the next, connecting one concept to another, connecting one skill to related skills, connecting one day's work to the next, or even one semester's ideas to the next ".

The Integrated Science learning model will be more successful if supported by audiovisual media so that students not only hear the learning material but also can see it directly. Thus, students will better understand the material delivered effectively and efficiently so that it is expected to be able to improve learning outcomes and science process skills.

\section{Research Aim}

The purpose of this study is to determine the effectiveness of integrated science type connected learning models with audiovisual teaching materials in achieving basic competencies and improving science process skills in Biochemistry 1 Subject with Basic Materials for Protein and Carbohydrates.

\section{RESEARCH METHOD}

This study uses a development research model suggested by Sivasailam Thiagarajan, Dorothy S. Semmel, and Melvyn I. Semmel (Thiagarajan, 1974). This model consists of 4 stages of development, namely Define, Design, Develop, and Disseminate, or adapted into a 4-D model, namely the definition, design, development, and dissemination. The learning model used in this research is Integrated Science or Integrated Science connected type with scientific methods and teaching materials in the form of learning videos. The Integrated Science learning model in this study is focused on achieving science process skills which include observing, interpreting data, communicating, and applying concepts. 


\section{Instrument and Procedures}

This educational research uses tests as instruments. This technique is used to see learning outcomes through the posttest. Also, data was collected by assessing students' science process skills using observation sheets. The observed science process skills are the ability to observe, interpret, communicate, and apply concepts. The results of observing science process skills by five observers by referring to the observation sheet are listed in Table 1.

Table 1. Observations of students' science process skills.

\begin{tabular}{ccccccc}
\hline \multirow{2}{*}{$\begin{array}{c}\text { Attendance } \\
\text { Number }\end{array}$} & \multicolumn{5}{c}{ Indicator of SPS } & \multicolumn{1}{c}{ Criteria } \\
\cline { 2 - 5 } & Observe & Interpret & Communicate & $\begin{array}{c}\text { Apply } \\
\text { concepts }\end{array}$ & Total & \\
\hline 1 & 2 & 3 & 3 & 2 & 10 & Medium \\
2 & 3 & 3 & 3 & 3 & 12 & High \\
3 & 3 & 3 & 3 & 4 & 13 & High \\
4 & 3 & 3 & 3 & 3 & 12 & High \\
5 & 4 & 3 & 4 & 3 & 14 & High \\
6 & 3 & 4 & 2 & 3 & 12 & High \\
7 & 3 & 3 & 3 & 4 & 13 & High \\
8 & 4 & 4 & 4 & 4 & 16 & High \\
9 & 3 & 4 & 3 & 4 & 14 & High \\
10 & 3 & 3 & 4 & 4 & 14 & High \\
11 & 3 & 3 & 3 & 4 & 13 & High \\
12 & 3 & 3 & 3 & 3 & 12 & High \\
13 & 2 & 3 & 2 & 3 & 10 & Medium \\
14 & 3 & 3 & 3 & 3 & 12 & High \\
15 & 3 & 3 & 3 & 3 & 12 & High \\
16 & 3 & 3 & 3 & 3 & 12 & High \\
17 & 3 & 4 & 3 & 3 & 13 & High \\
18 & 3 & 3 & 2 & 3 & 11 & Medium \\
19 & 3 & 3 & 3 & 4 & 13 & High \\
20 & 3 & 3 & 3 & 3 & 12 & High \\
\hline Average & & & & & $\mathbf{1 2} .5$ & High \\
\hline & & & & & & \\
\hline
\end{tabular}

\section{Data Analysis}

The data collected in this study were analyzed with the reliability and validity test of the device and learning media as well as the test of the difficulty level of the questions for the test instruments. Besides, the posttest data were analyzed by t-test using SPSS 23 software for windows. To measure the science process skills of student's observation is done through observation sheets with a value rating.

\section{RESULTS AND DISCUSSION}

Integrated learning is a new trend in responding to the development of 21st-century science and can provide new perspectives for educators and students in understanding the conceptual relationships, new models, and scientific structures between scientific disciplines. Integrated learning makes learning more relevant, effective, efficient, and provides variations in teaching styles (Mc.Cowan \& Knapper, 2002). 
Science learning, including chemistry, is also recommended to implement an integrated learning model, so that it is often known as Integrated Science. Integrated Science-Based learning models more often use themes to establish a cohesiveness between disciplines, so this model is also often referred to as thematic learning (Muqoyyanah et.al, 2010).

Integrated science learning developed is expected to provide meaningfulness for students. Said to be meaningful because students gain learning experiences that prioritize skills and attitudes to indicate changes in behavior. Hamalik (2001) states that "Learning outcomes are patterns of change in actions, values, understandings, attitudes, appreciation, and skills. Learning outcomes are accepted by students if they satisfy their needs and are useful and meaningful to them ". Meanwhile, Kusmardinah (2017) said that someone is said to have experienced a learning process if there is a change in behavior from not knowing to know, from not being able to, and so on.

Students who have self-experience in gaining science process skills are expected to become prospective teachers who can develop science process skills for their students later. Bearing in mind the Minister of Education and Culture Regulation No. 65 of 2013 has mandated a thematic and thematic approach integrated into the standard curriculum learning process of 2013 (K-13). Chemistry learning cannot be separated from thematic approaches that prioritize systematic scientific inquiry. This means that prospective chemistry teachers must have the scientific process skills contained in scientific inquiry.

Science Process Skills are skills that are derived from the training of basic mental, physical, and social abilities as drivers of higher abilities. Science process skills include observing, grouping, concluding, and communicating (Deden, 2013). Through the application of science process skills, learning becomes more holistic, active, and meaningful (Wiyanto \& Widiyatmoko, 2016). The basis of science process skills is observation using the five human senses, namely the eyes, nose, skin, tongue, and ears which produce based on the observed qualitative data. Science process skills (SPS) include basic science process skills and integrated science process skills. Process skills basic is a skill to be able to make observations, inference, measure, communicate, classify, and can predict, while the process what is meant by integrated process skills is that skill able to control variables, provide operational definitions, can formulate a hypothesis, interpret data, and can do experiments (Rustaman, 2015).

Science process skills (SPS) are divided into two groups (Karamustafaoğlu, 2011), namely Basic SPS and integrated SPS. Basic science process skills and integrated science process skills must be trained so that students not only become recipients of information, but also can find information related to the things learned (Limatahu \& Mubarok, 2020). This educational research was conducted on 20 students of Chemistry Study Program Bengkulu University Semester V Class A. The research itself goes through 4 stages, namely the stages of defining, designing, developing, and disseminating. The following is a description of the results of each research stage.

\section{Define}

The definition phase needs to be done considering the Integrated Science type connected learning model combines 3 subjects in one learning activity. This research itself combines material in the subjects Biochemistry, Organic Chemistry, Natural Materials (KOBA), and Biotechnology. The main material given to students is Protein 
and Carbohydrate contained in the syllabus of Biochemistry Course I. The main material on Protein discussed includes amino acids, amino acid structure, protein function, and enzymes, while the material sub-topic on Carbohydrates discussed is glycolysis. The KOBA material discussed in the study is related to the isolation of secondary metabolites and TLC Bioautography as a method of detection, while the Biotechnology material discussed is the application of biotechnology in agriculture, especially biological control by utilizing bioagents.

\section{Design}

The results of research at the design stage in the form of learning tools namely lecture unit, posttest questions, and learning videos. Following is the description of the results of the learning kit by 3 lecturers as validators.

\section{Lecture Unit Validation Results}

The results of the panelist/validator assessment of the lecture unit based on statistical tests showed the moment product correlation value $\left(\mathrm{r}_{\mathrm{xy}}\right)$ of 0.62 . This implies that the lecture unit is consistent and trustworthy so that it can be used in learning with the Integrated Science type connected model. Lecture Unit aspects assessed by panelists/ validators in the form of format, content, language, and writing, as well as the benefits of the Lecture Unit. The results of the assessment on a scale of 4 can be seen in Figure 1 .

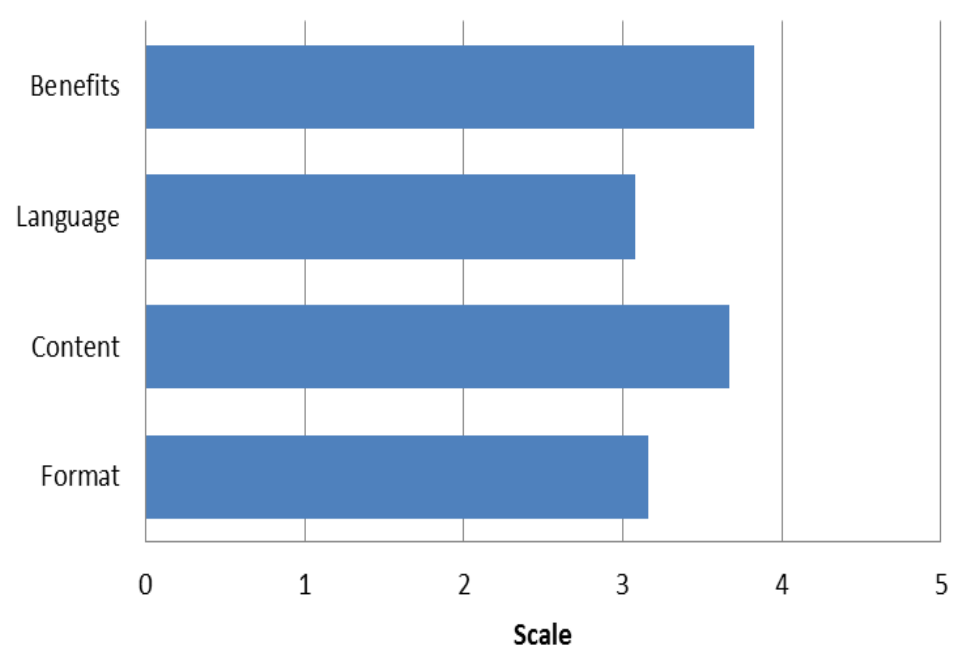

Figure 1. The result of lecture unit validation.

Based on Figure 1, aspects of the format in Lecture Unit compiled to get a score of 3.16 from a scale of 4 , this shows that the lecture unit format is in a good category. The content aspect got a score of 3.67 which is also in a good category which shows that competency standards (SK), basic competencies (KD), and material are following the concept of integrated science type connected developed so that it can be used to achieve learning objectives.

Aspects of language and writing got a score of 3.08 which is also in the good category. Likewise, with the aspect of benefits that received the highest score reached 3.83. The beneficial aspect of The Lecture Unit is also in the good category; this shows that SAP is considered to be able to provide benefits to increase the success of the learning process. 


\section{Instrument Reliability Test Results}

The results of the panelist test analysis of the test instrument showed a value of instrument reliability ( $\mathrm{r} 11$ ) of 0.66 . This value is categorized as high. This shows that the results of expert assessment of instruments are consistent and reliable so that the instruments that have been prepared can be used in learning with Connected type Integrated Science models.

\section{Learning Media Quality Validation Results}

Aspects assessed by validators related to the quality of learning videos include readability of text and sentences displayed in the video, the attractiveness of video display, image clarity, and animation, compatibility (media can be run on existing hardware and software), quality dialogue/ narration/ human voice, use of standard sentences and easy to understand, reusability (easy to use/ run and simple in operation). Based on the validation test, the product-moment value of 0.615 is included in the high validity category. This means that the learning videos that are made have good quality to be used as teaching media.

Table 2. Content validity of learning video quality.

\begin{tabular}{cccrc}
\hline $\begin{array}{c}\text { Source of } \\
\text { Variance }\end{array}$ & $\begin{array}{c}\text { Sum of } \\
\text { Squares }\end{array}$ & $\begin{array}{c}\text { Degrees of } \\
\text { Freedom } \\
(\mathbf{d f})\end{array}$ & $\begin{array}{c}\text { Mean } \\
\text { Square }\end{array}$ & $\begin{array}{c}\text { Coefficient } \\
\text { Correlation } \\
\left(\mathrm{r}_{\mathrm{xy}}\right)\end{array}$ \\
\cline { 1 - 3 } Item & 2.866 & 14 & 0.276 & \\
Evaluator & 0.033 & 1 & 0.033 & 0.615 \\
Error & 2.466 & 14 & 0.106 & \\
\cline { 1 - 3 } Total & 5.366 & 29 & & \\
\hline
\end{tabular}

\section{Validation Test Results for Learning Video Material Content}

The learning media developed in this study are learning videos that integrate 3 materials in the course that is Biochemistry, Organic Chemistry Natural Materials (KOBA), and Biotechnology. The biochemical material presented in this video is related to the process of glycolysis. The KOBA material presented is related to secondary metabolite compounds and their purification processes. The third material presented in this video is the use of biotechnology in everyday life.

The items assessed by validators include the correctness of the concept in the video, the coverage of the material with the learning objectives to be achieved, the suitability of the demonstration with the material, the suitability of the material with SK and KD, logic, wrinkling, and systematic. Besides, it is also assessed the depth of the material following the students' level of thinking, the ease of the material to be understood by students, as well as presenting learning that contains integrated components.

The results of the validation test of the contents of the learning video material give a value of $r_{x y}$ of 0.63 which is included in the high validity category. This figure shows that the contents of the material in the learning video are following with the learning objectives to be achieved and the level of thinking of students. 
Tabel 3. Content validity of learning video materials.

\begin{tabular}{lllll}
\hline Source of Variance & Sum of Square & $\begin{array}{c}\text { Degrees of } \\
\text { Freedom } \\
(\mathbf{d f})\end{array}$ & Mean Square & $\begin{array}{c}\text { Coefficient } \\
\text { Correlation } \\
\left(\mathrm{r}_{\mathrm{xy}}\right)\end{array}$ \\
\hline Item & 4.444 & 14 & 0.31746 & \\
Evalutor & 3.377 & 2 & 1.6889 & 0.63 \\
Error & 3.288 & 28 & 0.11746 & \\
\hline Total & 11.11 & 44 & & \\
\hline
\end{tabular}

\section{Development}

This stage is the development of learning tools by observing the review of the results of panelist validation. In this stage also a revision was made the product is then continued with the test empirical conducted on students of Chemistry Education FKIP Bengkulu University Semester V Class B. The results of the empirical test are as follows.

\section{Validity Test Results}

The validity test results using the calculation of the person correlation coefficient are as follows. Problems that have a $r_{x y}$ value of less than 0.3 are question numbers 15 and 17, so the questions are not valid criteria. Henceforth, this question is not used in the test instrument.

Table 4. Content validity of a test.

\begin{tabular}{llllll}
\hline Question Number & $\mathbf{r}_{\mathbf{x y}}$ & Criteria & $\begin{array}{l}\text { Question } \\
\text { Number }\end{array}$ & $\mathbf{r}_{\mathbf{x y}}$ & Criteria \\
\hline 1 & 0.54 & Valid & 10 & 0.60 & Valid \\
2 & 0.68 & Valid & 11 & 0.40 & Valid \\
3 & 0.44 & Valid & 12 & 0.48 & Valid \\
4 & 0.54 & Valid & 13 & 0.48 & Valid \\
5 & 0.48 & Valid & 14 & 0.44 & Valid \\
6 & 0.68 & Valid & 15 & 0.29 & Not Valid \\
7 & 0.54 & Valid & 16 & 0.60 & Valid \\
8 & 0.48 & Valid & 17 & 0.23 & Not Valid \\
9 & 0.44 & Valid & 18 & 0.48 & Valid \\
\hline
\end{tabular}

\section{Reliability Test Results}

The reliability test results show that the value of $R=0.731$, this indicates a value of more than 0.6 so that it meets the reliable criteria.

\section{Difficulty Test Results}

The results of the level of difficulty test carried out indicate that the questions with numbers 2 and 6 fall into the easy category, while questions number 15 and 17 fall into the hard category. Questions with easy categories are not used in research, nor are questions with difficult categories. Based on the results of the validity test, reliability, and level of difficulty it can be concluded in the following Table 5. 
Table 5. Empirical test result.

\begin{tabular}{lllllll}
\hline \multirow{2}{*}{ Question Number } & \multicolumn{2}{l}{ Validation } & Reliability & \multicolumn{2}{l}{ Difficulty } & Conclusion \\
\cline { 2 - 6 } & $\mathbf{r}_{\mathbf{x y}}$ & Criteria & $\mathbf{P}$ & Criteria & \\
\hline 1 & 0.54 & Valid & 0.65 & Medium & Used \\
2 & 0.68 & Valid & 0.75 & Easy & Discarded \\
3 & 0.44 & Valid & 0.55 & Medium & Used \\
4 & 0.54 & Valid & 0.65 & Medium & Used \\
5 & 0.48 & Valid & 0.60 & Medium & Used \\
6 & 0.68 & Valid & 0.75 & Easy & Discarded \\
7 & 0.54 & Valid & 0.65 & Medium & Used \\
8 & 0.48 & Valid & 0.60 & Medium & Used \\
9 & 0.44 & Valid & 0.55 & Medium & Used \\
10 & 0.60 & Valid & R=0.731 (reliable) & 0.70 & Medium & Used \\
11 & 0.40 & Valid & 0.50 & Medium & Used \\
12 & 0.48 & Valid & 0.60 & Medium & Used \\
13 & 0.48 & Valid & 0.60 & Medium & Used \\
14 & 0.44 & Valid & 0.55 & Medium & Used \\
15 & 0.29 & Not Valid & 0.35 & Hard & Discarded \\
16 & 0.60 & Valid & 0.65 & Medium & Used \\
17 & 0.23 & Not Valid & 0.45 & Hard & Discarded \\
18 & 0.4 & Valid & 0.60 & Medium & Used \\
\hline
\end{tabular}

Based on the Table above, it can be concluded that questions that meet the criteria and can be used are 14 items, that is question number $1,3,4,5,7,8,9,10.11,12,13,14,16$ and 18.

\section{Disseminate}

The implementation of the Integrated Science-Based Learning type Connected consists of four phases, namely Opening, Presentation, Guiding and Providing Training, and Closing. The four phases are syntax that must be implemented as a whole. In this research phase, the results of the posttest and science process skills of students. The following are the results of statistical tests on posttest scores and students' science process skills.

\section{Description of Learning Outcomes Test Data}

Learning with the Connected type Integrated Science model assisted with audiovisual teaching materials carried out in this study was conducted after the learning tools in the form of SAP and the question instruments and observation sheets met the criteria. The learning was carried out at the Chemistry Education students of Universitas Bengkulu Semester V Class A as much 2 times face to face ( 4 × 50 minutes). Evaluation of learning outcomes in the form of a posttest is done at the end of the second face-to-face learning presented in Table 6. 
Table 6. The data of posttest.

\begin{tabular}{ccc}
\hline Number & Category & Value \\
\hline 1. & Minimum & 71.43 \\
2. & Maximum & 92.86 \\
3. & Average & 85.36 \\
4. & Standard Deviation & 10.87 \\
\hline
\end{tabular}

Table 6 shows that the average student learning outcomes are 85.36 and in the complete category is more than minimal completeness criteria (KKM) set at 75 . This shows the average student grade in the completion category. The maximum value obtained by students is 92.86 and the minimum value is 71.43 . Classically students have reached KKM. Students' mastery learning can be achieved if the learning model and media used can provide meaningful experiences for students. In this case, the integrated science type connected learning model can make students have direct experience so that they can add strength to receive, save and apply the concepts they have learned (Trianto, 2014). The use of audiovisual media in the integrated science type connected model in this study provides a real picture of abstract material so that students can understand the concepts conveyed. Haryoko (in Taufiq, 2014) said that the use of audiovisual learning media can improve learning outcomes higher than conventional learning.

\section{Science Process Skill Test Results}

The students' science process skills (SPS) were held on the second face-to-face meeting. The students' science process skills were observed by five observers who were provided with observation sheets. The science process skills assessed are the ability to observe, interpret, communicate, and apply concepts.

Table 7. Analysis of students' science process skills (SPS).

\begin{tabular}{ccc}
\hline Category & Number of Students & Percentage (\%) \\
\hline Very high & 4 & 20 \\
High & 13 & 65 \\
Medium & 3 & 15 \\
Low & 0 & 0 \\
Very Low & 0 & 0 \\
\hline Total & 20 & 100
\end{tabular}

Table 7 shows that the science process skills of most students in the high category are $65 \%$, the very high category is $20 \%$ and enough category is $15 \%$. This shows that in general students' science process skills are in the high category. The score of science process skills for observing ability reached $87.5 \%$, interpreting reaching $81.25 \%$, communicating reaching $96.25 \%$, and applying the concept reaching $75 \%$ (presented in Figure 2). 


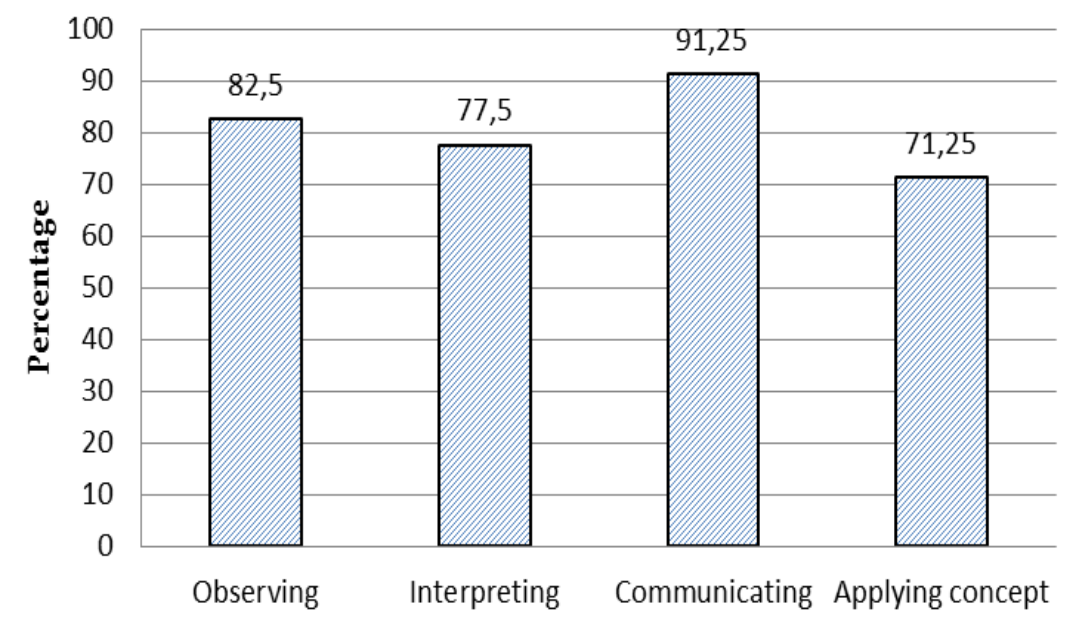

Science Process Skills

Figure 2. Percentage of mastery students' Science Process Skills (SPS).

The percentage of student mastery in every aspect of process skills assessed through observation by five observers can be seen in Figure 2. Based on research data, students' mastery of communication skills is the highest at $91.25 \%$. This indicates that students can be said to have been able to present the results of learning activities systematically and clearly and be able to use various sources of information in answering questions about the material presented. Students' mastery of the aspects of observing and interpreting skills is quite high. The ability to observe and interpret is a basic process skill that students must have (Tawil \& Liliasari, 2014). Without this ability, students will find it difficult to digest lecture material delivered by lecturers to make the expected basic competencies not be achieved.

The percentage of observing skill mastery which reached $82.5 \%$ shows that students have been able to use all five senses to find facts based on observations, both in the slide material and in the learning video presented. The percentage of mastery of interpreting skills reaches $81.25 \%$, this shows that students are quite capable of making assumptions or hypotheses based on patterns of the relationship of the results of observational information and can make an overview. If the ability of students in mastering skills, observing, interpreting, and communicating is at a high enough level, the results differ from the ability of students to apply concepts/principles that only reach $71.25 \%$. Although students can be quite capable of using concepts in new experiences to explain what is happening, this shows that the ability to apply concepts is more difficult to master compared to other abilities. This happens because students have not been able to understand the interrelationship between concepts in the integrated science learning materials provided, where this research combines material from 3 courses namely Biochemistry, Organic Chemistry, Natural Materials (KOBA), and Biotechnology. Another factor that makes the percentage of mastery of skills/ ability to apply concepts is lower than other abilities because students are not accustomed to honing their science process skills. Students will be able to master the science process skills if they receive continuous training in learning so that they can be retained in long-term memory (Yanto, 2019). Matlin (in Yusuf \& Wulan, 2015) states that information processing in the formation of concepts is easier to be called (recall/recognition) if stored in long-term memory, especially in the form of pictures. 


\section{CONCLUSION}

The results of research and discussion show that the Connected type Integrated Science model that is used effectively to improve student learning outcomes and science process skills. Mastery of students' science process skills for indicators of observation, interpretation, and communicating to be in the high category. However, the mastery of science process skills for indicators applying concepts is lower because students have not been able to understand the interrelationship of concepts in the integrated science learning material provided. Thus, integrated science type connected learning models with audio-visual teaching materials can be recommended to be applied in schools to improve learning outcomes and science process skills. More in-depth research on science process skills for all indicators is strongly recommended to obtain more comprehensive results.

\section{REFERENCES}

Deden. (2013). Peningkatan keterampilan proses sains menggunakan metode eksperimen dalam pembelajaran IPA kelas VI SDN 47 Rambin Sanggau. Jurnal Pendidikan dan Pembelajaran Khatulistiwa, 2(4),1-12.

Hamalik, O. (2001). Proses belajar mengajar. Jakarta: Bumi Aksara.

Karamustafaoğlu, S. (2011). Improving the science process skills ability of science student teachers using I diagrams. Eurasian Journal of Physics and Chemistry Education, 3(1), 26-38.

Kusmardinah. (2017). Pembelajaran kooperatif index card match disertai laboratorium virtual untuk meningkatkan kualitas proses dan hasil belajar kimia materi pokok laju reaksi pada siswa kelas Xi-Mia SMA Muhammadiyah 3 Surakarta semester gasal tahun pelajaran 2017/2018. Jurnal Pendidikan Empirisme, 23(6), 167-178.

Limatahu, I., \& Mubarok, H. (2020). CCDSR learning model: innovation in physics learning. IJORER: International Journal of Recent Educational Research, 1(1), 19-29. https://doi.org/10.46245/ijorer.v1i1.13

Mc.Cowan, J.D. , \& Knapper, C.K. (2002). An integrated and comprehensive approach to engineering curricula, part one: Objectives and general approach. Journal of Engineering Education, 18(6), 633-637.

Muqoyyanah, Rusilowati, \& Sulhadi. (2010). Efektivitas dan efisiensi model pembelajaran IPA. Jurnal Pendidikan Fisika Indonesia, 6, 44-47.

Organisation for Economic Co-operation and Development. (2019). PISA 2018 Result combined executive summaries volume I, II, \& III.. https://www.oecd.org/pisa/Combined_Executive_Summaries_PISA_2018.pdf

Prabowo, S.A. (2015). The effectiveness of scientific based learning towards science process skills mastery of PGSD students. Indonesian Journal of Science Education, 4(1), 15-19. https:/ / doi.org/10.15294/jpii.v4i1.3495

Pratiwi, I. (2019). Efek program PISA terhadap kurikulum di Indonesia. jurnal pendidikan dan kebudayaan, 4(1), 55-71.https:/ / doi.org/10.24832/jpnk.v4i1.1157

Ridyah, S.W., \& Sriyati, S. (2016). Pembelajaran IPA terpadu tipe connected model experiential learning untuk meningkatkan keterampilan proses sains siswa SMP. Edusains, 8(2), 122-127.

Rustaman, N. (2015). Strategi belajar mengajar biologi. Malang: Universitas Negeri Malang. 
Taufiq, M., Dewi, N.R., \& Widiyatmoko, A. (2014). Pengembangan model pembelajaran IPA terpadu berkarakter peduli lingkungan tema konservasi berpendekatan science-edutainment. Jurnal Pendidikan IPA Indonesia, 3(2), 140-145. https:// doi.org/10.15294/jpii.v3i2.3113

Tawil, M., \& Liliasari. (2014). Keterampilan-keterampilan sains dan implementasinya dalam pembelajaran IPA. Makassar: Badan Penerbit Universitas Negeri Makassar.

Thiagarajan, S. (1974). Instructional development for teacher of exceptional children. Indiana: Bloomington.

Trianto. (2014). Model pembelajaran terpadu. Jakarta: Bumi Aksara.

Wiyanto \& Widiyatmoko, A. (2016). Preparation model of student teacher candidate in developing integrative science learning. Journal of Education and Human Development, 5(2), 169-177. https:// doi.org/10.15640/jehd.v5n2a20

Yanto. (2019). Engineering psychology: Prinsip dasar rekayasa kerja berbasis integrasi fisik, psikis, dan teknik. Jakarta: UKI Atma Jaya.

Yusuf, M., \& Wulan, A., R. (2015). Penerapan model pembelajaran discovery learning menggunakan pembelajaran tipe shared dan webbed untuk meningkatkan keterampilan proses sains. Jurnal Penelitian \& Pengembangan Pendidikan Fisika, 1(2), 19-26.

\section{*Emilia Candrawati, M.Pd. (Corresponding Author)}

Science Education Study Program, Universitas Bengkulu

WR Supratman St, Kandang Limun. Bengkulu, 38123, Indonesia

Email: emiliacandrawati@unib.ac.id

\section{Dr. Sumpono, MS.}

Graduate School of Science Education, Universitas Bengkulu

WR Supratman St, Kandang Limun. Bengkulu, 38123, Indonesia

Email: sumpono1960@gmail.com

\section{Dr. Agus Sundaryono, M.Si.}

Graduate School of Science Education, Universitas Bengkulu,

WR Supratman St, Kandang Limun. Bengkulu, 38123, Indonesia

Email: agussundaryono@gmail.com

\section{Mellyta Uliyadari, M.Pd.Si.}

Science Education Study Program, Universitas Bengkulu

WR Supratman St, Kandang Limun. Bengkulu, 38123, Indonesia

Email: mellytauliyandari@unib.ac.id 